\section{Compression and sports}

\author{
Jean-Patrick Benigni \\ French University Group for Medical \\ Compression, Saints Peres University, \\ Paris, France
}

\section{Introduction}

Sportsmen are healthy people who theoretically do not suffer from disabling chronic venous disorders. In these subjects, wearing compressions is not helpful. But the search for a better performance pushed the sporting world to look for devices that can improve muscle performance especially at the calf. The use of compression stockings (CS) is widespread. Their usefulness should be demonstrated. This is the purpose of this abstract. The expected effects of wearing compression stockings during or after sport are: i) improved performance and recovery; ii) acceleration of blood flow; iii) increase of oxygen supplied to the muscles; iv) elimination of toxins.

\section{Clinical studies of sports per- formance}

Evidence from clinical trials is paradoxically poor. Only one study showed an improvement of performance after sub maximal running. ${ }^{1}$ It studied the contribution of CS after a run on a treadmill. Jump height has been improved with less fatigue and better feeling of comfort.

After short duration sprints from 10 to $60 \mathrm{~m}$, no real improvement on performance could be shown. ${ }^{2-5}$

In endurance racings, only one study showed a discreet effect of CS (18-20 mmHg) after running on the treadmill, the running time and lactate levels. All other studies ${ }^{6-9}$ did not show a conclusive difference (cycling, running and netball).

A compression garment on the upper body ${ }^{10}$ also did not show improved performance among kayakers.

\section{Effects on paraclinical parameters}

During endurance races, ${ }^{11}$ no significant difference in $\mathrm{VO}^{2} \max$, blood lactates and $\mathrm{O}^{2}$ consumption was found.

Concerning the cardio-respiratory function, one study showed a significant effect on oxygen consumption, $\mathrm{O}_{2}$ pulse, and local blood flow. However, these improvements appear trivial to athletes, as they did not correspond to any improvement in endurance running performance. Other published studies did not find any particular effects. ${ }^{12-14}$

Concerning temperature, 3 studies s,7,15 $^{2,1}$ showed that wearing CS increased skin temperature but not body temperature.

\section{Effects on proprioception and muscle oscillations}

A study ${ }^{16}$ demonstrated improved proprioception, which can be explained by stimulating cutaneous receptors and decreasing muscle oscillations during vertical jumps.

But such findings are questionable among runners.

\section{Clinical studies during recovery}

During the recovery phase after a race of endurance there is clearly a positive effect on symptoms (fatigue, swelling, muscle pain) if CS are worn during the race. ${ }^{13,17,18}$ Positive effects of CS, wearing on the post-exercise pain, persist for 48 to $72 \mathrm{~h}$ after exercise. Wearing CS also improves muscle performances during the recovery phase with positive effects on jump height 24 to $96 \mathrm{~h}$ after exercise.

\section{Effects on lactate}

In a study, ${ }_{19}$ the authors compare the kinetics of lactate wearing a CS $(18 \mathrm{mmHg}$ at the ankle and $8 \mathrm{mmHg}$ at the calf) versus no CS.

Under CS, 15 min after exercise, the lactate levels were lower with CS than without CS. But if $\mathrm{CS}$ are removed just after the effort, lactate levels were higher in the CS group than in the group without $\mathrm{CS}$. This means that CS retained lactate in the muscle.

\section{After a marathon}

In a case-control study, ${ }^{20}$ after a marathonrun the authors showed a positive effect of wearing CS for $48 \mathrm{~h}$ on muscle fatigue and swelling.

\section{A surprising finding}

A recent study ${ }^{21}$ demonstrates that wearing CS reduces muscle oscillations and inflamma-
Correspondence: Jean-Patrick Benigni, French University Group for Medical Compression, Saints Peres University, 45 rue des Saints Pères 75005 Paris, France.

E-mail: benigni.jp@orange.fr

This work is licensed under a Creative Commons Attribution 4.0 License (by-nc 4.0).

(C) Copyright J-P. Benigni et al., 2016

Licensee PAGEPress, Italy

Veins and Lymphatics 2016; 5:5992

doi:10.4081/vl.2016.5992

tory lesions assessed by muscle biopsy $48 \mathrm{~h}$ after a race of $40 \mathrm{~min}$ on a treadmill. These data could explain the beneficial effects of CS observed during recovery.

\section{What can we conclude from these studies?}

Published studies are very different and it is difficult to give clear conclusions. It seems obvious that CS wearing has no effect on performance during a sprint.

The effects appear marginal during an endurance effort.

However, there is sufficient evidence to claim that CS wearing has an effect on pain during recovery up to $48 \mathrm{~h}$ after exercise. The exact mechanisms are discussed (reduction of inflammatory lesions, improving venous flow, etc.). New studies are needed among amateur runners to study new generations of CS.

Partsch and Mosti22,23 have shown that in venous patients conventional graduated CS improve the calf muscle pump slightly, but that higher pressure over the calf (progressive CS) is more effective. Similarly, stiff bands wrapped over the calf with a pressure of 30-40 $\mathrm{mmHg}$ narrow deep veins and lead to an increase of the ejection fraction of the calf pump in healthy sports people.

\section{References}

1. Rugg S, Sternlicht E. The effect of graduated compression tights, compared with running shorts, on counter movement jump performance before and after sub maximal running. J Strength Cond Res 2013;27:1 067-73.

2. Doan B, Kwon Y, Newton R, et al. Evaluation of a lower body compression garment. J Sports Sci 2003;21:601-10.

3. Kraemer W, Bush J, Newton R, et al. Influence of a compression garment on 
repetitive power output production before and after different types of muscle fatigue. Sports Med Training Rehabil 1998;8:16384.

4. Uffield R, Portus M. Comparison of three type of full-body compression garments on throwing and repeat-sprint performance in cricket players. Br J Sports Med 2007;41:409-14.

5. Faulkner JA, Gleadon D, Mclaren J, Jakeman JR. Effect of lower-limb compression clothing on 400-m sprint performance. J Strength Cond Res 2013;27:669-76.

6. Sperlich B, Haegele M, Achtzehn S, et al. Different types of compression clothing do not increase sub-maximal and maximal endurance performance in well-trained athletes. J Sports Sci 2010;28:609-14.

7. Higging T, Naughton G, Burgess D. Effects of wearing a compression garment on physiological and performance measures in a simulated game-specific circuit for netball. J Sports Sci 2009;12:223-6.

8. Berry M, Mcmurray R. Effects of graduated compression stockings on blood lactates following an exhaustive bout of exercise. Am J Phys Med 1987;66:121-32.

9. Scalan A, Dascombe B, Reaburn P, Osborne M. The effects of wearing lower body compression garments during endurance cycling. Int $\mathrm{J}$ Sports Physiol Perform 2008;3:424-38.

10. Dascombe B, Laursen P, Nosaka K, Polglaz
E. No effect of upper body compression garments in elite-flat-water kayakers. Eur J Sport Sci 2013;13:341-9.

11. Born D, Sperlich B, Holmberg H. Bringing light into the dark: effects of compression clothing on performances and recovery. Int J Sports Physiol Perform 2013;8:4-18.

12. Dascombe B, Hoare T, Sear J, et al. The effects of wearing undersized lower-body compression garments on endurance running performance. Int $\mathrm{J}$ Sports Physiol Perform 2011;6:160-73.

13. Mac Rae BA, Cotter JD, Laing R. Compression garments and exercise, garments considerations, physiology and performance. Sports Med 2011;41:815-43.

14. Sperlich B, Haegele M, Krüger M, et al. Cardio-respiratory and metabolic responses to different levels of compression during sub maximal exercise. Phlebology 2011;26:102-6.

15. Houghton LA, Dawson B, Maloney SK. Effects of wearing compression garments on thermoregulation during simulated team sport activity in temperate environmental conditions. J Sci Med Sport 2009;12:303-9.

16. Kraemer W, Bush J, Newton R, et al. Influence of a compression garment on repetitive power output production before and after different type of muscle fatigue. Sports Med Training Rehabil 1998;8:16384.
17. Ali A, Creasy R, Edge J. The effect of graduated compression stockings on running performance. J Strength Cond Res 2011;25:1385-92.

18. Jakemann J, Byrne C, Eston R. Lower limb compression garment improves recovery from exercise induced muscle damage in young, active females. Eur J Appl Physiol 2010;109:1137-44.

19. Berry M, Mcmurray R. Effects of graduated compression stockings on blood lactates following an exhaustive bout of exercise. Am J Phys Med 1987;66:121-32.

20. Allaert FA, Gardon-Mollard C, Benigni JP. Effect of compression stockings (18-21 $\mathrm{mmHg}$ ) on muscular adaptation and recovery of the marathoners. Phlébologie 2011;64:57-62.

21. Borràs X, Balius X, Drobnic F, et al. Effects of lower body compression garments in muscle oscillation and tissular injury during intense exercise. Muscles Ligaments Tendons J 2014;3:295-302.

22. Partsch H, Mosti G. The progressive medical CS increase the capacity of the venous pump of the calf than the conventional graduated CS. Phlébologie 2012,65:13-8.

23. Partsch H, Mosti G. Sport socks do not enhance calf muscle function but inelastic wraps do. Int Angiol 2014;33:511-7. 